\title{
Neoliberal Policies and English Language Education in Turkey
}

\author{
Omer Gokhan Ulum ${ }^{1}$ \\ ${ }^{1}$ English Language Teaching Department, Education Faculty, Mersin University, Mersin, Turkey \\ Correspondence: Omer Gokhan Ulum, English Language Teaching Department, Education Faculty, Mersin \\ University, Mersin, Turkey.
}

Received: July 20, 2020

Accepted: August 11, 2020

Online Published: August 13, 2020

doi: 10.5539/elt.v13n9p63

URL: https://doi.org/10.5539/elt.v13n9p63

\begin{abstract}
Turkey has adopted a new trend regarding English-medium education in recent decades. The development of capitalism has also affected Turkey and the Turkish education system. The Turkish Council of Higher Education has aspired to make higher education in Turkey more global and international. Therefore, the British Council has prepared a report to show the situation of English in Turkey. It has been found that Turkey needs serious ameliorations in many ways in the sphere of English-medium instruction. The report findings show that Turkey can develop economically more if it can endorse English-based education. The popularity of neoliberalism has shown its effects in Turkish higher education. Therefore, English has been prioritized as a result of neoliberalism. In the future, the situation of English can be evaluated by teachers, scholars, students, policymakers, and international organizations. The findings also show that The Turkish Council of Higher Education believes that the British Council has contributed to the development of English in Turkey following neoliberal policies.
\end{abstract}

Keywords: neoliberalism, capitalism, the British Council, English language education

\section{Introduction}

Neoliberal practices and policies aim to commodify any entity by minimizing the effect of the public and governmental intervention (Klees, 2008) and by mainly using and even expanding the principles of laissez-faire economic movement and the free market (Olssen \& Peters, 2005) whose origins date back to $19^{\text {th }}$ century and which led neoliberalism to emerge in the 1970s with new definitions by using democracy and populism as an effective tool (Giroux, 2002; Harvey, 2007; Guardino, 2018). Thus, the free-market in neoliberalism has been conceptualized in a fundamentalist way since it is based on only market-centric policies (Harvey, 2007; McMurtry, 2002). This study will focus on only lingua nullius (Kayman, 2009; Phillipson, 2018) since British Council aims to show that English should be an indispensable part of Turkish universities if Turkey intends to be integral to internationalization and economic globalization, which indicates the neoliberal practices of the British Council (Taquini, Finardi, \& Amorim, 2017). The neoliberal aim of British Council along with the US dates back to early $20^{\text {th }}$ century (Phillipson, 2008) because the presidents and the authorities of these countries have been insistently and visibly developing discourses and strategies to show that English is the only global language and solution to be economically strong on a global scale (Pennycook, 2017; Block \& Gray, 2016; Shin, 2016; Price, 2014; Skutnabb-Kangas \& Phillipson, 2010; Olssen \& Peters, 2005). This lingua nullius project has been supported by academia to suggest that learning English is the sine qua non of global and individual success in every sphere of life including politics, culture, business, and education (Grengs, 2005). In line with this idea, Philipson (2017) notes the fact that the English language has commercial and geopolitical strategies. These neoliberal practices of lingua nullius can also be best seen in the market of English global textbooks by commodifying the English language in particular (Bori, 2020; Bada \& Ulum, 2017; Ulum, 2014; Ulum \& Bada, 2016). English language teaching in three circles (inner, outer and expanding ones) (Ulum \& Köksal, 2019; Ulum, 2016; Kachru, 1992; 2006) has been largely influenced by neoliberal policies by degrading the importance of teaching less commonly used languages which are economically at a disadvantage because English has been shown as a lingua franca (Pennycook, 2017; Phillipson, 2008; Ryan, 2006). Turkish scholars (Doğançay-Aktuna \& Kiziltepe, 2005; Kirkgoz, 2005; 2009) have strictly followed and largely supported these neoliberal practices of lingua nullius by emphasizing that Turkish schools and universities need to develop more efficient policies to promote English Medium Education.

This study indicates that English as a second language should be more widespread in Turkey, although it is already common and established in Turkey if Turkey aims to be an international and global culture. Turkish 
Council of Higher Education and the British Council evaluated the condition of English in Turkey within some Turkish universities. This study showed the statistical distribution of languages in Turkey and analyzed the speech made by the head of the Turkish Council of Higher Education as well as the 132-page report prepared by the British Council.

\section{Research Questions}

1. What themes does the Turkish Council of Higher Education emphasize based on the report prepared by the British Council?

2. What neoliberal policies have been emphasized in the report prepared by the British Council?

3. What languages other than English are prioritized in Turkey?

\section{Methodology}

Discourse analysis is a method that has come to have diverse meanings for scholars working in different domains. For a sociolinguist, it involves the structure of social interaction uttered in conversations (Brown \& Yule, 1983). This paper employed a discourse analysis (Brown \& Yule, 1983; Fairclough \& Wodak, 1997; Potter \& Edwards, 1996; Johnstone, 2017) of a speech and a written report by giving the statistical distribution of different languages taught and studied in Turkey. The themes extracted from the report are five-fold, which can be listed as globalization, the language of education, education in English, English as a medium in departments' quality of universities, curriculum, English in preparatory programs of Turkish universities by ranking the situation of English in the world and Europe.

\subsection{British Council Report}

The report involved some universities in Turkey. To emphasize the importance of the report nationwide, a lot of media agencies were invited to release the events and news regarding the study. Besides, some short videos and photographs of the events were released publicly. Social media was also extensively used to announce the report findings.

\section{Findings}

The findings of the report demonstrate that English education presented in Turkey needs to be enhanced. Four events were held within the framework of the report. In the first event, the framework of the report was introduced to The President of the Council of Higher Education (YÖK) and Rectors, Directors of Schools of Foreign languages, international agencies, and UK publishers. The second event was held at a Turkish university to share the first data obtained from the report. The third and fourth events, which showed the implicit neoliberal and cultural imperialist aims of the British Council, were organized at two Turkish universities in 2016 and 2017. The third event was titled 'Cultivation of quality Culture in ELT in Higher Education', which inherently emphasizes British culture that is shown as a superior culture in Turkey. The fourth event was titled 'Exploring English, skills, employability: Industry, alumni and academia', which refers to neoliberal and global practices of the British Council. Thus, the third and fourth events intend to impose British culture and commercial interests of the British Council.

\subsection{Preliminary Findings}

There are 27 language departments including the Turkish language itself in Turkish universities. There are 466 language departments in Turkey. 260 of these departments are composed of foreign languages. 138 of them are merely English. Turkish and English language departments account for 206 and 138 out of 466 language departments, respectively. $73.8 \%$ of the language departments are composed of only Turkish and English. Considering second language departments, $29.6 \%$ of them consist of only English departments. $6.22 \%$ of them are composed of German departments. $4.08 \%$ and 2.79 of them are composed of French and Arabic/Russian languages respectively. Thus, it can be said that English departments far outweigh other foreign language departments. 


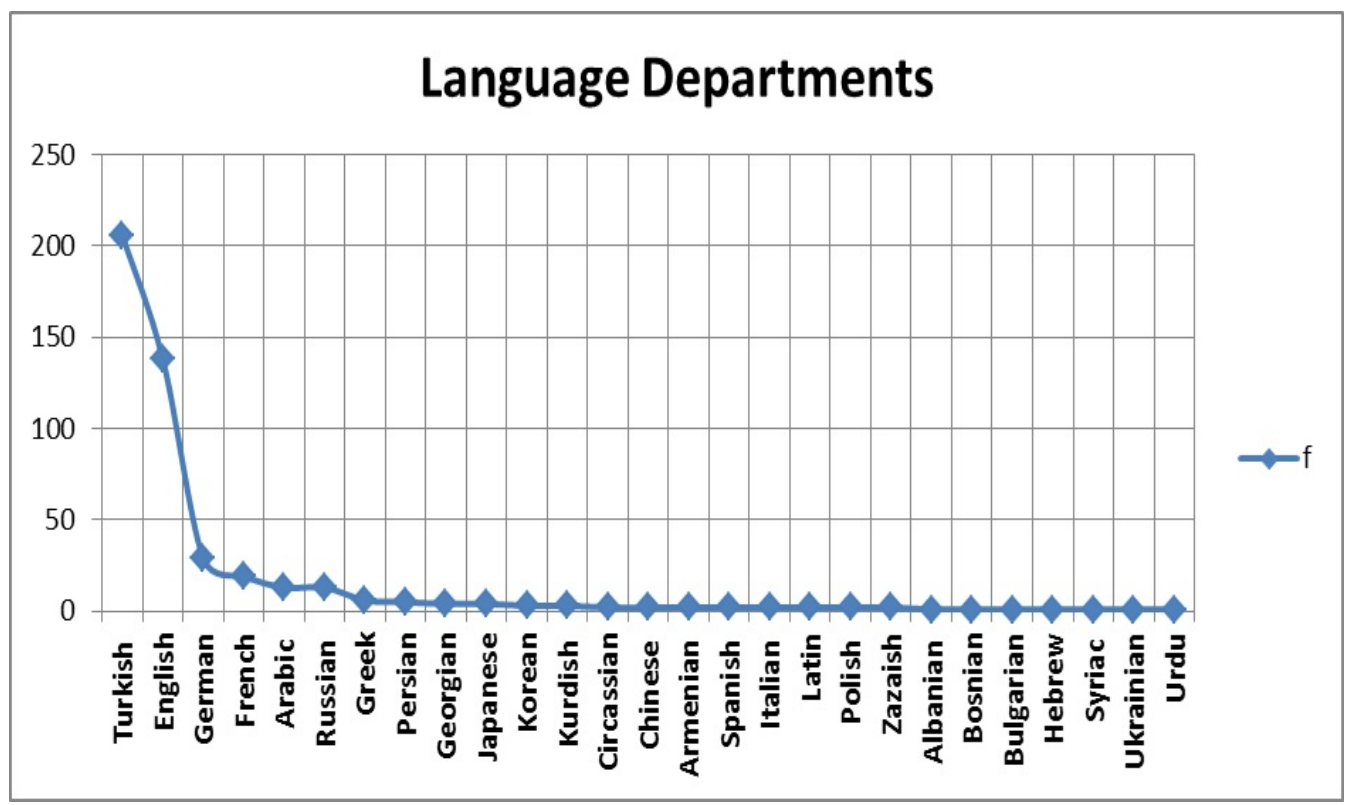

Figure 1. Language Departments Stated in the Turkish Council of Higher Education

Figure 1 shows that the Turkish Language Departments received the highest ratio (44.2\%), followed by English Language Departments (29.6\%). Further, German Language Departments got a lower frequency (6.2\%), as well as French Language Departments with a considerably lower rate (4.1\%). Arabic Language Departments had the same frequency as Russian Language Departments (2.8\%). When we examined Greek (1.3\%) and Persian (1.1\%) Language Departments, we saw that the frequency of these departments was remarkably scarce. Overall, the following language departments emerged with the slightest frequencies: Georgian Language Departments (0.9\%); Japanese Language Departments (0.9\%); Korean Language Departments (0.6\%); Kurdish Language Departments (0.6\%); Circassian Language Departments (0.4\%); Chinese Language Departments (0.4\%); Armenian Language Departments (0.4\%); Spanish Language Departments (0.4\%); Italian Language Departments (0.4\%); Latin Language Departments (0.4\%); Polish Language Departments (0.4\%); Zazaish Language Departments (0.4\%); Albanian Language Departments (0.2\%); Bosnian Language Departments (0.2\%); Bulgarian Language Departments (0.2\%); Hebrew Language Departments (0.2\%); Syriac Language Departments (0.2\%); Ukrainian Language Departments (0.2\%); and Urdu Language Departments $(0.2 \%)$. In brief, results trended towards Turkish and English Language Departments. The next coming trend within this category is comprised of German, French, Arabic, and Russian Language Departments though appeared in scarce frequencies.

The percentage was chosen for showing the stated frequency because it is very useful when comparing sets of data. In the analysis, the data from the Turkish Council of Higher Education were extracted and categorized according to language departments. Overall, a prominent trend is observed for English Language Departments $(53.1 \%)$ while it is pursued by such departments as German (11.2\%), French (7.3\%), Arabic (5.0\%), and Russian (5.0\%) departments. As Figure 2 shows, Greek (2.3\%), Persian (1.9\%), Georgian (1.5\%), and Japanese (1.5\%) language departments are observed to be occurring in slight numbers. The rarest emergence was detected in the pursuing foreign or second language departments: Korean language departments (1.2\%); Kurdish language departments (1.2\%); Circassian language departments (0.8\%); Chinese language departments (0.8\%); Armenian language departments (0.8\%); Spanish language departments $(0.8 \%)$; Italian language departments $(0.8 \%)$; Latin language departments (0.8\%); Polish language departments (0.8\%); Zazaish language departments $(0.8 \%)$; Albanian language departments (0.8\%); Bosnian language departments (0.8\%); Bulgarian language departments (0.8\%); Hebrew language departments (0.8\%); Syriac language departments (0.8\%); Ukrainian language departments $(0.8 \%)$; and Urdu language departments $(0.8 \%)$. Thus, it is simply detected from the figure that results inclined towards English Language Departments. The following inclination within this category is composed of German, French, Arabic, and Russian Language Departments though appeared in scant ratios. 


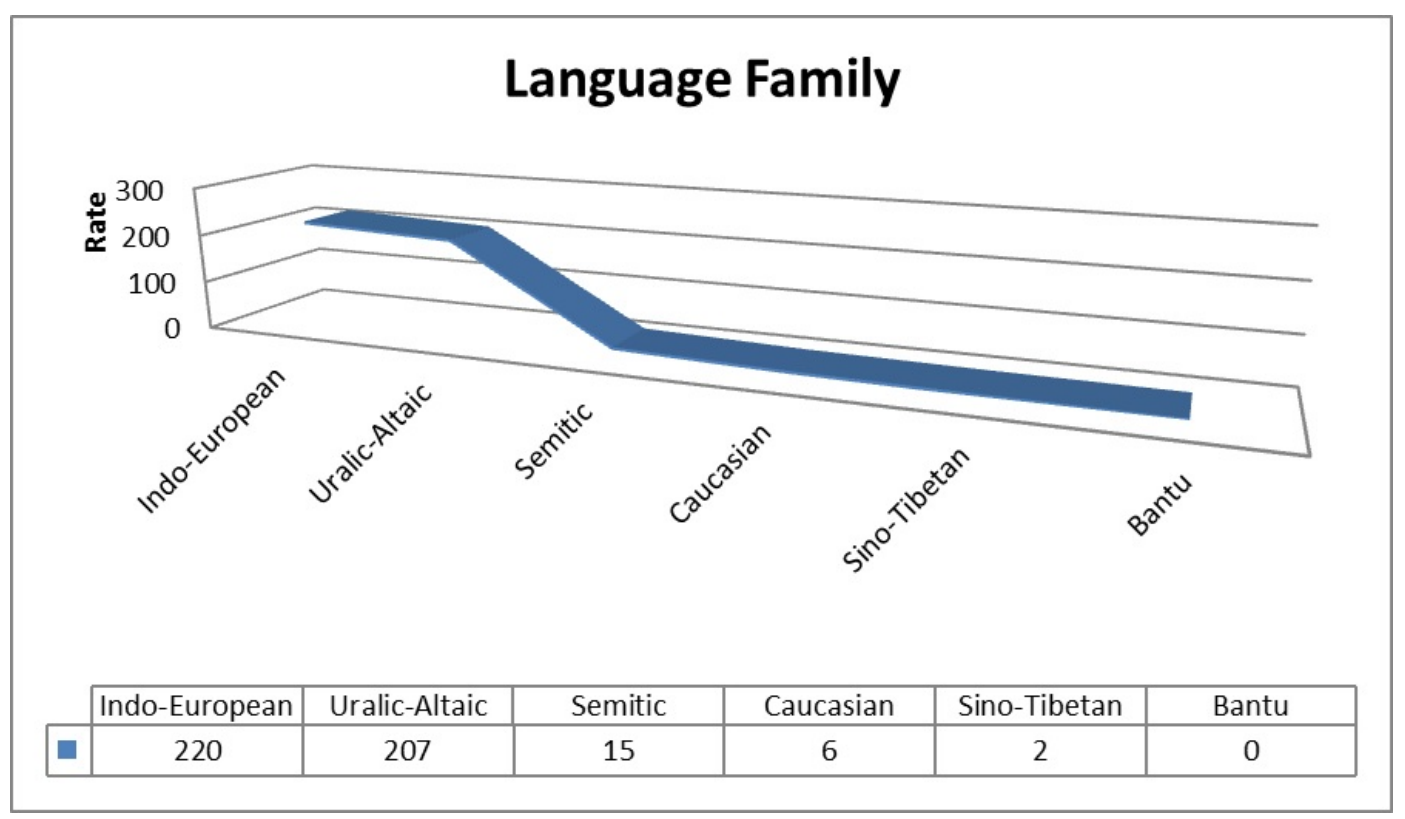

Figure 2. Dispersion of Language Departments based on Origin Structured Family Trees

Figure 2 indicates a tendency towards Indo-European Languages (48.9\%) which is followed by Uralic-Altaic Languages (46.0\%). Most of the Indo-European languages are composed of English, German and French languages. However, the analysis showed that departments of Semitic (3.3\%) and Caucasian (1.3\%) languages were observed at remarkably low ratios. While the departments related to Sino-Tibetan Languages $(0.4 \%)$ emerged at a profoundly low rate, the departments in Bantu Languages were exceptionally noted with no occurrence. To sum up, a remarkable tendency towards Indo-European (English) and Uralic-Altaic (Turkish) Language Departments are detected at outstanding rates while no occurrence was observed in the departments related to Bantu (African) languages.

\subsection{Findings Related to British Council Report}

\subsubsection{Ethical Problems}

Although the report claimed that it conformed to ethical issues and would be anonymous and confidential, the names of the universities were shared publicly. Besides, a detailed ethical procedure was not explained. The report made paradoxical explanations about ethical issues because the participants and the classes were not informed by the university administrators. After all, the Turkish Council of Higher Education decided on how the procedure, regardless of individuals' own decision to participate in the study, would proceed. Thus, ethical considerations at the individual level were ignored.

\subsubsection{Internationalization and Globalization}

It is interesting that the first dimension of the study focused on and was titled globalization, which shows the main goal of the British Council. The report explicitly expresses that the insufficiency of English makes it hard for Turkey to be able to keep up with global economies. To show the insufficiency of English education, the report analyzed Turkish universities' ranking on a global scale, research performance, Bologna process, student mobility in Europe. The report found that Turkish universities still need amelioration in all these four areas while having made slight progress. The expert from the British Council started his presentation by emphasizing the weaknesses in English education on both national and global scale and terminated his speech by focusing on the needs of reform at each level in Turkey.

While analyzing the situation of Turkey, the report used international and global financial terms many times to stress that the insufficiency of English causes Turkey not to be able to find a place in the global market. The report also shows some references by including Russia, China, South Korea, Japan, and Germany which aimed to prioritize English in their education system. This observation of the report gave the impression that Turkey should also prioritize English education in the Turkish education system. Otherwise, Turkey would continue to fall short of globalization. In terms of research performance, the report emphasized that Turkish scholars are not recognized on a global scale because of the weaknesses in English education and that Turkish scholars' academic English was found to be inadequate. Therefore, academic English should be taught to Turkish scholars. Since 
English is insufficient (Ulum \& Uzun, 2020), this negative situation in English harms the academic performance of Turkish scholars. As for the Bologna Process, the report says that if Turkey aims to internationalize at a global scale and global market, then Pearson and other related accreditation processes should be applied in English education. Thus, the success of the Bologna process is ascribed to success in English by using the global market such as Pearson. Lastly, student mobility can be more successful if English becomes more widespread in Turkey and Turkish universities because student mobility is too low in Turkey when compared to the numbers in the USA, the United Kingdom, Germany, France, and Australia. It is implied that international students hardly prefer Turkey because of insufficiency in English education. It has also been emphasized that most of the university students aimed to study or work in the USA or the United Kingdom. Besides, it was noted that studying in the United Kingdom and the USA is profitable for Turkish students who aim to improve their English or to hold MA and Ph.D. degrees. After the report focused on the weaknesses in English education in Turkey, it explicitly suggests that Turkey should accelerate and spread the use of English from elementary to university level for both learners and teachers as well as academics and civil servants.

\subsubsection{National Education System in Turkey}

The overall findings of the report show that the participants in the study prefer to continue their studies in their mother tongue since it provides more in-class discussion between students and lecturers because insufficiency in the English language hinders the quality of classes as students have difficulty discussing issues in English. Besides, even lecturers experience these difficulties when they intend to produce English in classrooms. The report emphasizes that it is because of administrative issues that English is chosen as a medium of instruction.

The report shows that the history of Turkish universities using English as a medium of instruction dates back to 1863, 1956, and 1984. It was found that undergraduates and lecturers in these universities prefer Turkish to English since it was better and more efficient for them to follow classes in Turkish and that the level of English taught in preparatory programs was insufficient. Therefore, it is suggested that long-term goals need to be achieved. Insufficiency in English puts serious psychological and motivational problems for both undergraduates and lecturers, although the importance of English was emphasized by the participants in the study. Thus, the advantages and disadvantages obtained from the study are paradoxical. The weaknesses in the report imply that Turkish universities need to prioritize the English language if Turkey aims to take its place in the global economy.

\subsubsection{Discourse Analysis of Speech of the Turkish Council of Higher Education}

The speech focused on the English language as a medium of instruction at Turkish universities by relating English language education to globalization. It was emphasized that Turkey could take its place in the globalized world by increasing the number of Turkish universities and departments that use English as a medium of instruction. The head of the Turkish Council of Higher Education insistently emphasized that learning and teaching English at higher institutions should not be limited only language education but should be considered an important part of globalization. The head of the Turkish Council of Higher Education noted that academic programs that use English as a medium of instruction contribute to the demands of businesses on a global scale by helping students to acquire competence in English. The speech implies that English education should be understood within the framework of globalization by cooperating with the British Council. It was also reported that the Turkish Council of Higher Education and the British Council have been organizing piloted studies and supervising more than 15 universities to ensure that international and national standardization can be obtained. Both institutions attempted to base their justification on scientific studies to open more room for neoliberal practices in Turkey and aimed to serve economically global needs. The speech ignored other international and national languages in Turkey and does not offer any suggestions for other languages. English has been constantly prioritized in the speech by disregarding less commonly spoken languages. For example, the Turkish Council of Higher Education has never opened any department regarding African languages, although the number of African students has increased dramatically in recent years.

\section{Discussion}

The report seems to be supporting the spread of English. As a neoliberal agent, British Council is visible. However, the Turkish Council of Higher Education has been unable to develop a critical perspective (Ordem \& Ulum, 2019) towards the use of English and has tended to ignore other foreign languages because English in particular, German and French languages have been prioritized. Turkish and English language education is prevalent in Turkey. Turkish scientists (Doğançay-Aktuna \& Kiziltepe, 2005; Kirkgoz, 2007; 2009) assume that English can be common in Turkey. Thus, English can be spread in Turkey and Greece by adopting neoliberal policies (Sifakis, 2007; 2009; 2014). The British Council has often supported the policies of English in Turkey. 
Also, the Turkish Council of Higher Education has not developed any policy that could integrate other minority and foreign languages (Köksal \& Ulum, 2018; 2020, Ulum \& Köksal, 2020; Ulum 2015a; 2015b). Philipson (1992) articulates that English is used as a centric component of neoliberalism. Philipson (2017) notes that 'Global' English is a project to establish English as the language of the neoliberal empire serviced by global finance whatever the consequences for other cultures and languages. The policies of the Turkish Council of Higher Education seems to have been serving this commercial purpose, the idea of which is also supported by Turkish researchers. Philipson (2017) stresses the fact that the British Council is the main visible agent that promotes and accelerates the expansion of English. The report findings also show that English education should be expanded in Turkish universities under the name of globalization and global needs. Philipson (2017) mentions a similar report announced in India, It is called English Next India. What is striking is that similar results are also in the report announced for Turkey by emphasizing that Turkish learning of English is insufficient (Ulum \& Uzun, 2020), English is the key success of globalization, and British Council has the solution to Turkey's language in education problem. Similarly, the British Council 2015 report in Turkey does not mention any geopolitical, geostrategic, commercial, military, and cultural benefits at all. Besides, the report emphasizes that only British Council experts can organize and address English language education topics. Similar report findings are observed in the English Next India report (Philipson, 2017). Turkish Council of Higher Education announced another report prepared in 2017 regarding African students in Turkey by saying that $8 \%$ of international students, almost 10.000 ones, come from Africa. However, no African language is taught in Turkey, and the Turkish Council of Higher Education has not developed any policy that could represent these languages. In a more general 2017 report about the internationalization of Turkish universities, weaknesses of the report were composed of eight items, three of which were about second language education implicitly referring to English language education. This report shows striking similarities to the British Council 2015 report, which also stresses the weaknesses of English language education in Turkey. It seems that the Turkish Council of Higher Education encourages Turkish universities to serve neoliberalism strictly endorsed by British Council. Lingua nullius also tends to create linguicism directly or indirectly because if English is shown as an un-ideological, neutral, universal, and global lingua franca, then the disappearance of local, national, and international languages in a certain country can be shown as a natural process. Performativity of gender emphasized by Butler may also apply to this linguistic context because language similar to gender is constantly practiced and exercised (Ordem \& Ulum, 2020). Thus, linguicism becomes a normal daily exercise by showing that languages disappear naturally, although institutes such as British Council use all means composed of so-called scientific surveys, social media, videos, organization of conferences and others academic events to make so-called lingua franca more widespread by repeating the same weaknesses of countries waiting to be postcolonialized. A lot of events have been held regarding the English language by ignoring other languages or studies regarding these languages such as African ones, Asian, and Arabic.

\section{Conclusion}

This study shows that the Turkish higher education system can develop English-medium instruction by enhancing the quality of English. It also demonstrates that the Turkish universities should be international and global by supporting the spread of English. This policy has some similarities to other countries such as South Korea. The report prepared by the British Council reinforces the policies of the Turkish Council of Higher Education. Future studies can deal with other reports, policies, and materials to see the course of English in Turkey. Besides, the views of learners, teachers, and administrators can be taken into consideration to develop better policies about the condition of English. Other international reports can also be analyzed and assessed to gain insights and reflect upon the policies in Turkey. Critical approaches and perspectives can be improved to pave way for the use of English and even other languages. Neoliberal policies can be approached with a critical lens so that policies can be university-friendly. If Turkey desires to be global and economically strong, the spread of English has been emphasized in the report. The policies of the Turkish Council of Higher Education also seem to have been adopting these economic and international aims.

\section{References}

Bada, E., \& Ulum, Ö. G. (2017). English: Well beyond the inner circle dominance. Journal of Human Sciences, 14(4), 3932-3939. https://doi.org/10.14687/jhs.v14i4.5002

Block, D., \& Gray, J. (2016). Just go away and do it and you get marks: the degradation of language teaching in neoliberal times. Journal of Multilingual and Multicultural Development, 37(5), 481-494. https://doi.org/10.1080/01434632.2015.1071826

Bori, P. (2020). Neoliberal governmentality in global English textbooks. Classroom Discourse, 11(2), 149-163. 
https://doi.org/10.1080/19463014.2020.1755327

Brown, G., \& Yule, G. (1983). Discourse Analysi. Cambridge Textbooks in Linguistics. Cambridge: Cambridge University Press. https://doi.org/10.1017/CBO9780511805226

Doğançay-Aktuna, S., \& Kiziltepe, Z. (2005). English in Turkey. World Englishes, 24(2), 253-265. https://doi.org/10.1111/j.1467-971x.2005.00408.x

Fairclough, N., \& Wodak, R. (1997). Critical discourse analysis. Discourse studies: A multidisciplinary introduction, 2, 357-378. https://doi.org/10.4135/9781446289068.n17

Giroux, H. (2002). Neoliberalism, corporate culture, and the promise of higher education: The university as a democratic public sphere. Harvard educational review, 72(4), 425-464. https://doi.org/10.17763/haer.72.4.0515nr62324n71p1

Grengs, J. (2005). The abandoned social goals of public transit in the neoliberal city of the USA. City, 9(1), 51-66. https://doi.org/10.1080/13604810500050161

Guardino, M. (2018). Neoliberal populism as hegemony: a historical-ideological analysis of US economic policy discourse. Critical Discourse Studies, 15(5), 444-462. https://doi.org/10.1080/17405904.2018.1442361

Harvey, D. (2007). Neoliberalism as creative destruction. The annals of the American academy of political and social science, 610(1), 21-44. https://doi.org/10.1177/0002716206296780

Johnstone, B. (2017). Discourse analysis. New Jersey: John Wiley \& Sons.

Kachru, B. B. (1992). Teaching World Englishes. In B. B. Kachru (Ed.), The other tongue. English across cultures (2nd ed., pp. 355-365). Urbana, IL: University of Illinois Press.

Kachru, B. B. (2006). The English language in the outer circle. World Englishes, 3, 241-255. https://doi.org/10.1016/b0-08-044854-2/00645-3

Kayman, M. A. (2009). The Lingua Franca of Globalisation:" filius nullius in terra nullius", as we say in English. Nordic Journal of English Studies, 8(3), 87-115. https://doi.org/10.35360/njes.199

Kirkgoz, Y. (2005). English language teaching in Turkey: Challenges for the 21 st century. In G. Braine (Ed.), Teaching English to the world: History, curriculum, and practice (pp. 159-175). London: Lawrence Erlbaum Associates.

Kirkgoz, Y. (2007). English language teaching in Turkey: Policy changes and their implementations. RELC Journal, 38(2), 216-228. https://doi.org/10.1177/0033688207079696

Kirkgoz, Y. (2009). Students' and lecturers' perceptions of the effectiveness of foreign language instruction in an English-medium university in Turkey. Teaching in higher education, 14(1), 81-93. https://doi.org/10.1080/13562510802602640

Klees, S. J. (2008). A quarter-century of neoliberal thinking in education: Misleading analyses and failed policies. Globalization, Societies, and Education, 6(4), 311-348. https://doi.org/10.1080/14767720802506672

Köksal, D., \& Ulum, Ö. G. (2020). Views of EFFL Instructors and Learners on Political Compounds in EFL Textbooks. i-manager's Journal on English Language Teaching, 10(1), 45-56. Retrieved from https://imanagerpublications.com/article/16573/

Köksal, D., \& Ulum, Ö. G. (2018). The state of EFL teacher education in Turkey: From pastcto present. ELT Research Journal, 7(4), 161-174. Retrieved from https://dergipark.org.tr/tr/pub/eltrj/issue/41754/483569

Kubota, R. (1998). Ideologies of English in Japan. World Englishes, 17(3), 295-306. https://doi.org/10.1111/1467-971x.00105

McMurtry, J. (2002). Value wars. The global market versus the life economy. London: Pluto. https://doi.org/10.5860/choice.40-4112

Olssen, M., \& Peters, M. A. (2005). Neoliberalism, higher education, and the knowledge economy: From the free market to knowledge capitalism. Journal of education policy, 20(3), 313-345. https://doi.org/10.1080/02680930500108718

Ördem, E., \& Ulum, Ö. G. (2019). Critical Pedagogy and Participatory Approach in Turkey: Views of Pre-service ELT teachers. Electronic Turkish Studies, 14(2), 679-693. https://doi.org/10.7827/turkishstudies.14655

Ördem, E., \& Ulum, Ö. G. (2020). Gender Issues in English Language Teaching: Views from Turkey. Acta 
Educationis Generalis, 10(1), 25-39. https://doi.org/10.2478/atd-2020-0002

Pennycook, A. (2017). The cultural politics of English as an international language. London: Routledge. https://doi.org/10.4324/9781315225593

Phillipson, R. (1992). Linguistic imperialism. Oxford: Oxford University Press.

Phillipson, R. (1999). Voice in global English: unheard chords in Crystal loud and clear. Review article on 'English as a global language' by D. Crystal. Applied Linguistics, 20(2), 288-299. https://doi.org/10.1093/applin/20.2.265

Phillipson, R. (2003). English-only Europe? Challenging language policy. London: Routledge. https://doi.org/10.4324/9780203696989

Phillipson, R. (2008). The linguistic imperialism of neoliberal empire. Critical Inquiry in Language Studies, 5(1), 1-43. https://doi.org/10.1080/15427580701696886

Phillipson, R. (2009). Linguistic imperialism continued. New York: Routledge, and Delhi: Orient Blackswan.

Phillipson, R. (2011). The EU and languages: diversity in what unity? In A. L. Kjær \& S. Adamo (Eds.), Linguistic diversity and European democracy (pp. 57-74). Farnham: Ashgate.

Phillipson, R. (2017). Myths and realities of global English. Language Policy, 16(3), 313-331. https://doi.org/10.1007/s10993-016-9409-z

Phillipson, R. (2018). English, the lingua nullius of global hegemony. In The Politics of Multilingualism: Europeanisation, Globalisation and Linguistic Governance (pp. 275-304). Amsterdam: Benjamins. https://doi.org/10.1075/wlp.6.12phi

Potter, J., \& Edwards, D. (1996). Discourse analysis. In Introducing psychological research (pp. 419-425). London: Palgrave. https://doi.org/10.1007/978-1-349-24483-6_63

Price, G. (2014). English for all? Neoliberalism, globalization, and language policy in Taiwan. Language in Society, 43(5), 567-589. https://doi.org/10.1017/s0047404514000566

Ryan, S. (2006). Language learning motivation within the context of globalization: An L2 self within an imagined global community. Critical Inquiry in Language Studies, 3(1), 23-45. https://doi.org/10.1207/s15427595cils0301_2

Shin, H. (2007). English language teaching in Korea: Toward globalization or glocalization?. In International handbook of English language teaching, Edited by Cummins, J. and Davison, C. Vol. 1, 75-86. Norwell, MA: Springer. https://doi.org/10.1007/978-0-387-46301-8_7

Shin, H. (2016). Language 'skills' and the neoliberal English education industry. Journal of Multilingual and Multicultural Development, 37(5), 509-522. https://doi.org/10.1080/01434632.2015.1071828

Sifakis, N. C. (2007). The education of the teachers of English as a lingua franca: a transformative perspective. International Journal of Applied Linguistics, $17, \quad 355-375$. https://doi.org/10.1111/j.1473-4192.2007.00174.x

Sifakis, N. C. (2009). Challenges in teaching ELF in the periphery: The Greek context. ELT Journal, 63, 230-237. https://doi.org/10.1093/elt/ccn057

Sifakis, N. C. (2014). ELF awareness s an opportunity for change: a transformative perspective for ESOL teacher education. Journal of English as a Lingua Franca, 3(2), 315-333. https://doi.org/10.1515/jelf-2014-0019

Skutnabb-Kangas, T., \& Dunbar, R. (2010). Indigenous children's education as linguistic genocide and a crime against humanity?: A global view (pp. 1-128). Kautokeino, Norway: Gáldu.

Skutnabb-Kangas, T. \& Phillipson, R. (2010). The global politics of language: markets, maintenance, marginalization, or murder. In Coupland, N. (Ed.), The Handbook of Language and Globalization (pp. 77-100). Malden, MA, and Oxford: Wiley-Blackwell. https://doi.org/10.1002/9781444324068.ch3

Skutnabb-Kangas, T. (2000). Linguistic genocide in education - or worldwide diversity and human rights? Mahwah, NJ: Lawrence Erlbaum.

Taquini, R., Finardi, K. R., \& Amorim, G. B. (2017). English as a medium of instruction at Turkish state universities. Education and Linguistics Research, 3(2), 35-53. https://doi.org/10.5296/elr.v3i2.11438

Ulum, Ö. G. (2014). Teachers' Views on "Yes You Can", the Ninth Grade English Coursebook for Public Schools. International Journal of Languages' Education and Teaching, 2(3), 132-148. 
https://doi.org/10.12973/jlle.11.293

Ulum, Ö. G. (2015a). EFL Policy of Turkey: Past and Present. International Journal of Development Research, 5(9), 5577-5580. Retrieved from https://eric.ed.gov/?id=ED577303

Ulum, Ö. G. (2015b). History of EFL Teacher Education Programs in Turkey. Journal of Research in Humanities and Social Science, 3(7), 42-45. Retrieved from https://eric.ed.gov/?id=ED577304

Ulum, Ö. G. (2016). To Culture or Not to Culture, That Is the Question! ELT Research Journal, 5(3), 218-233. Retrieved from https://eric.ed.gov/?id=ED577308

Ulum, Ö. G., \& Bada, E. (2016). Cultural Elements in EFL Course Books. Gaziantep University Journal of Social Sciences, 15(1), 15-26. https://doi.org/10.21547/jss.256738

Ulum, Ö. G., \& Köksal, D. (2019). Ideological and Hegemonic Practices in Global and Local EFL Textbooks Written for Turks and Persians. Acta Educationis Generalis, 9(3), 66-88. https://doi.org/10.2478/atd-2019-0014

Ulum, Ö. G., \& Köksal, D. (2020). Ideology and Hegemony of English Foreign Language Textbooks: Globally and Locally Written Practices. Berlin: Springer Nature. https://doi.org/10.1007/978-3-030-35809-9

Ulum, Ö. G., \& Uzun, K. (2020). Critical Perspective of English Teaching and Learning in Turkey. International Journal of Evaluation and Research in Education, 9(2), 456-460. https://doi.org/10.11591/ijere.v9i2.20469

\section{Copyrights}

Copyright for this article is retained by the author(s), with first publication rights granted to the journal.

This is an open-access article distributed under the terms and conditions of the Creative Commons Attribution license (http://creativecommons.org/licenses/by/4.0/). 